\title{
Digestibility and bioavailability of organic calcium sources for European quail
}

\section{Digestibilidade e biodisponibilidade de fontes orgânicas de cálcio para codornas Europeias}

\author{
Ana Patrícia Alves Leão ${ }^{1}$; Sandra Roseli Valerio Lana ${ }^{2 *}$; Geraldo Roberto Quintão \\ Lana $^{2}$; Romilton Ferreira de Barros Junior ${ }^{3}$; Daniela da Silva Mendonça4; \\ Thalis José de Oliveira ${ }^{3}$
}

\section{Highlights:}

The evaluated organic calcium sources have high apparent digestibility coefficients.

The true digestibility coefficients of the studied sources were higher than $89 \%$.

The organic calcium sources could be used in quail feed formulations.

\begin{abstract}
The objective of this study was to determine the apparent and true digestibility coefficients and relative bioavailability of charru mussel, maçunim (Anomalocardia brasiliana) and oyster shells as organic calcium sources for meat quail. In the digestibility trial, 240 quail were distributed in a completely randomized experimental design with five diets (calcitic limestone, calcium carbonate and three marine calcium sources), five replicates and eight quails per experimental unit. The relative bioavailability of calcium was determined by the standard-curve and slope ratio methods in a growth trial in which 288 European quail were distributed in completely randomized experimental design. Treatments consisted of basal diet with a low calcium concentration $(0.166 \%)$ that was supplemented with two levels of calcium $(0.342 \%$ and $0.684 \%)$ derived from different calcium sources. The apparent and true digestibility coefficients of calcium from charru mussel-, maçunim- and oyster-shell meals for meat quail were 91.85 and $92.04 \%$; 91.71 and $91.90 \%$; and 89.39 and $89.63 \%$, respectively. The relative bioavailability of calcium from charru mussel-, maçunim- and oyster-shell meals obtained using standard-curve and slope ratio methods were 133.22 and $119.18 \% ; 140.05$ and $113.69 \%$; and 141.73 and $106.22 \%$, respectively, allowing the use of these organic calcium sources in diet formulations for meat quail.
\end{abstract}

Key words: Anomalocardia brasiliana. Charru mussel. Coturnix coturnix. Oysters. Quail farming.

1 Discente do Curso de Doutorado do Programa de Pós-Graduação em Zootecnia, Departamento de Zootecnia, Universidade Federal de Lavras, UFLA, Lavras, MG, Brasil. E-mail: anapatriciaalvesleao@gmail.com

2 Profs. Drs., Departamento de Zootecnia, Centro de Ciências Agrárias, Universidade Federal de Alagoas, UFAL, Rio Largo, AL, Brasil. E-mail: sandraroselilana@gmail.com; geraldoquintaolana@gmail.com

3 Discentes do Curso de Doutorado do Programa de Pós-Graduação em Zootecnia, Departamento de Zootecnia, Universidade Federal da Paraíba, UFPB, Areia, PB, Brasil. E-mail: romilton.barros@bol.com.br; thalis-oliveira2011@hotmail.com

4 Discente do Curso de Mestrado do Programa de Pós-Graduação em Zootecnia, Departamento de Zootecnia, Centro de Ciências Agrárias, UFAL, Rio Largo, AL, Brasil. E-mail: danimendonca95@gmail.com

* Author for correspondence 


\section{Resumo}

O objetivo deste estudo foi determinar os coeficientes de digestibilidade aparente e verdadeiro e a biodisponibilidade relativa de conchas de sururu, maçunim (Anomalocardia brasiliana) e ostra como fontes orgânicas de cálcio para codornas de corte. No ensaio de digestibilidade, 240 codornas foram distribuídas em um delineamento inteiramente casualizado constituído de cinco dietas (calcário calcítico, carbonato de cálcio e três fontes marinhas de cálcio), cinco repetições e oito aves por unidade experimental. A biodisponibilidade relativa do cálcio foi determinada pelo método da curva padrão e Slope Ratio em um ensaio de crescimento no qual 288 codornas Europeias foram distribuídas em um delineamento inteiramente casualizado. Os tratamentos consistiram em uma dieta basal, com baixa concentração de cálcio $(0,166 \%)$ a qual foi suplementada com dois níveis de cálcio $(0,342 \%$ e $0,684 \%)$ proveniente das diferentes fontes de cálcio. Os coeficientes de digestibilidade aparente e verdadeiro das farinhas de conchas de sururu, maçunim e ostra, para codornas de corte foram 91,85 e 92,04\%; 91,71 e $91,90 \%$; e 89,39 e $89,63 \%$, respectivamente. A biodisponibilidade do cálcio das farinhas de conchas de sururu, de maçunim e de ostra obtidas utilizando-se os métodos da curva padrão e Slope Ratio foram 133,22 e $119,18 \% ; 140,05$ e $113,69 \%$; e 141,73 e 106,22\%, respectivamente, permitindo o uso destas fontes orgânicas de cálcio na formulação de ração para codornas de corte.

Palavras-chave: Anomalocardia brasiliana. Coturnicultura. Coturnix coturnix. Ostra. Sururu.

\section{Introduction}

Calcium and phosphorus are two of the major minerals required for excellent development of poultry (Kim et al., 2017). However, these minerals are found in small quantities in corn and soybean meal, the main ingredients used in the feeding of these animals. Therefore, their supplementation is necessary.

According to Santana et al. (2018), the most commonly used sources of calcium for supplementation originate from calcareous rocks (limestone and phosphates). It is known that, over the years, this extraction may nonetheless have adverse effects on the environment. This scenario warrants the development of a production system that, in addition to being sustainable throughout time, also contributes to environmental sustainability.

In the state of Alagoas, Brazil, the improper disposal of shells of bivalve mollusks such as charru mussel, maçunim (Anomalocardia brasiliana) and oysters at lagoon edges has aroused a great deal of interest in the possibility of using them in animal diets, given their high calcium contents.

Before including them as ingredients in animal diets, producers must know how much of the calcium present in these sources can be utilized by the animal. Then, by knowing the digestibility of a given feedstuff, it is possible to determine the percentage of the nutrient that was absorbed in relation to its intake. Bioavailability, in turn, involves the metabolism and utilization of a nutrient; i.e., it refers to the effective utilization of the absorbed components (Sakomura \& Rostagno, 2007).

In view of the dearth of scientific information on this topic, the present study was conducted to determine the digestibility and bioavailability of charru mussel-, maçunim- and oyster-shell meals as organic sources of calcium in the diet of European quail.

\section{Materials and Methods}

All experimental procedures were approved by the Ethics Committee on Animal Use at UFAL (approval no. 66/2017). To determine the digestibility of different calcium sources originating from the coastal regions of Alagoas State, Brazil, 240 eight-day-old, non-sexed European quail were housed in metabolic cages equipped with individual feeders and drinkers and excreta-collection trays. The quail were kept in the cages for 10 days, which 
consisted of a five-day period of adaptation to the experimental diets followed by five days of total excreta collection.

The birds were allotted to one of five treatments (calcium sources) in a completely randomized design with five replicates and eight birds per experimental unit. A basal diet (BD) was formulated based on corn and soybean meal and supplemented with synthetic amino acids so as to meet the nutritional requirements as recommended by Silva and Costa (2009), except for calcium (0.166\%). The treatments consisted of the basal diet plus different calcium sources, as follows: BD + calcitic limestone; BD + calcium carbonate; $\mathrm{BD}+$ charru mussel shell meal; $\mathrm{BD}+$ maçunim shell meal; and $\mathrm{BD}+$ oyster shell meal. All test diets met the calcium requirement of $0.850 \%$.

Throughout the experimental period, water and feed were available ad libitum. Forty birds were distributed simultaneously into five cages where they were fed a diet with a low calcium content $(0.019 \%)$ to determine endogenous calcium losses, which were used to correct the true-digestibility values. Each diet received $1 \%$ of ferric oxide to mark the excreta from the first and last collection days.

The concentrations of dry matter (DM) and total calcium in the diets and excreta were analyzed at the Laboratory of Animal Nutrition at the Center for Agrarian Sciences, UFAL, and at Central Analítica Ltd., respectively, following the methodologies described by Silva and Queiroz (2006). The apparent digestibility coefficient (ADC) and the true digestibility coefficient (TDC) were calculated using the formulae proposed by Sakomura and Rostagno (2007).

For the calcium bioavailability trial, 288 nonsexed meat quail were used from eight to 21 days of age. The birds were allotted to one of nine treatments in a completely randomized design with four replicates and eight quail per experimental unit.

The basal diet was composed of corn and soybean meal and supplemented with vitamins, minerals and synthetic amino acids to meet the nutritional requirements as recommended by Silva and Costa (2009) for meat quail from one to 21 days of age, except for calcium, which was kept at a deficient level of $0.166 \%$. The treatments consisted of a basal diet with a low calcium concentration $(0.166 \%)$ and the same diet supplemented with two levels of calcium $(0.342 \%$ and $0.684 \%)$ derived from calcium carbonate or charru mussel-, maçunim- or oyster-shell meals.

The following variables were analyzed: weight gain (WG, g quail ${ }^{-1}$ ), feed intake (FI, g quail ${ }^{-1}$ ), feed conversion (FC), bone tensile strength (BTS, kgf) and bone ash content (BA, \%). Quail and diets were weighed at the start and end of the experimental period to measure the animal performance variables.

To determine the bone-related parameters, at 21 days of age, two birds with the average weight of each plot were identified and slaughtered to collect the left and right tibia. Bone tensile strength analyses were performed at the Laboratory of Structures and Materials (LEMA) integrated to the Research and Technologies Section at the Technology Center at UFAL. The bones (right tibiae) were placed in their natural state on a controlled testing machine (AG$\mathrm{X} 100 \mathrm{kN}$, Shimadzu), which records the tensile strength of materials. The left tibiae were used to determine the ash content.

The calcium bioavailability in the studied sources was determined by two methods, namely, the standard-curve method and the Slope Ratio method described by Sakomura and Rostagno (2007). In the standard curve method, a standard line was established where the linear equation was determined based on data of calcium intake from the standard diet $(\mathrm{X})$ and the dependent variables $\mathrm{Y}$ (weight gain, feed conversion, ash content and bone tensile strength). The obtained standard curve $(\mathrm{Y}=\mathrm{a}+\mathrm{bx})$ was used to estimate the bioavailability for a given response, based on the value $(Y)$ of the measured parameter of the test source (charru mussel-, maçunim- or oyster-shell meals). The corresponding amount of nutrient from the standard 
source (calcium carbonate) was also calculated. The ratio between the two values (charru mussel-, maçunim- or oyster-shell meals with calcium carbonate) indicated the comparative bioavailability of the nutrient in the respective test source (charru mussel-, maçunim- or oyster-shell meals).

For the slope ratio method, the data were fitted by the mathematical model of multiple linear regression equations, which were determined by considering the calcium intakes from the basal diet $(\mathrm{Xb})$ and from calcium carbonate (Xp), charru mussel shell meal (Xt1), maçunim shell meal (Xt2) or oyster shell meal (Xt3) and the responses, according to the following model: $\mathrm{Y}=\mathrm{a}+\mathrm{bbXb}+\mathrm{bpXp}+\mathrm{btXt1}$. The relative calcium bioavailability was calculated based on the coefficients of regression (b), considering the $\mathrm{b}$ of the standard source (calcium carbonate) as $100 \%: \mathrm{BDCa}=\mathrm{bt} / \mathrm{bp} \times 100$.

The obtained data were subjected to analysis of variance, which was followed by a mean comparison test (Tukey's test at the 5\% significance level), using R computer software (R Core Team [R], 2016).

\section{Results and Discussion}

In the digestibility trial, no significant differences were observed $(\mathrm{P}>0.05)$ for the apparent and true digestibility coefficients of calcium from calcium carbonate, calcitic limestone or charru mussel-, maçunim- and oyster-shell meals (Table 1). Conversely, Rezvani, Moradi and Izadi (2019) obtained greater digestibility of calcium from eggshell and oyster as compared with the treatment with an inorganic calcium carbonate. Additionally, in an experiment using charru mussel-, maçunimand oyster-shell meals for broiler hens, Lana (2017) reported differences $(\mathrm{P}<0.01)$ between the evaluated calcium sources for the apparent and true digestibility coefficients. However, the digestibility coefficients obtained in the present study were higher than those found by Lana (2017); e.g. calcitic limestone $(85.30 \%)$ and charru mussel- $(86.80 \%)$, maçunim- $(86.69 \%)$ and oyster-shell $(86.25 \%)$ meals.

\section{Table 1}

Apparent digestibility coefficient (ADC) and the true digestibility coefficient (TDC) and relative bioavailability of charru mussel, maçunim (Anomalocardia brasiliana) and oyster shells as organic calcium sources for meat quail

\begin{tabular}{lcccc}
\hline Calcium source & ADC $^{\text {ns }}(\mathbf{\%})$ & ARB $(\%)$ & TDC $^{\text {ns }}(\mathbf{\%})$ & TRB $\left.^{(\%)}\right)$ \\
\hline Calcium carbonate $^{1}$ & 90.27 & 100.00 & 90.50 & 100.00 \\
Calcitic limestone & 91.03 & 100.84 & 91.31 & 100.89 \\
Charru mussel shell meal & 91.85 & 101.75 & 92.04 & 101.70 \\
Maçunim shell meal & 91.71 & 101.59 & 91.90 & 101.55 \\
Oyster shell meal & 89.39 & 99.02 & 89.63 & 99.04 \\
\hline P-value & 0.646 & & 0.655 & \\
SEM & 1.29 & & 1.28 & \\
\hline
\end{tabular}

${ }^{\mathrm{n} s}$ not significant $(\mathrm{P}>0.05)$.

${ }^{1}$ Attributed to calcium carbonate $100 \%$ calcium bioavailability.

$\mathrm{SEM}=$ Standard error of the mean. 
The observed differences for apparent and true digestibility coefficients between the tested calcium sources may be explained by the variation in their calcium availability, which is represented by the chemical composition and physical association of calcium with other components that form compounds of low solubility and low availability.

By using the apparent and true digestibility coefficients of the calcium sources, it was possible to estimate the relative bioavailability of calcium carbonate, calcitic limestone and charru mussel-, maçunim- and oyster-shell meals. All studied sources were highly bioavailable (Table 1). Charru mussel shell meal showed a higher bioavailability value $(100.70 \%)$ than maçunim- and oyster-shell meals.

In the bioavailability trial, no significant differences were observed ( $\mathrm{P}>0.05)$ for feed intake between the calcium levels of 0.342 and $0.648 \%$ from calcium carbonate and charru mussel-, maçunim- and oyster-shell meals (Table 2).

Table 2

Production performance and bone parameters of quail fed calcium organics sources, from eight to 21 days

\begin{tabular}{|c|c|c|c|c|c|c|c|c|c|}
\hline \multirow[b]{2}{*}{ Diet } & \multirow{2}{*}{$\begin{array}{c}\begin{array}{c}\text { Calcium } \\
\text { level }\end{array} \\
(\%)\end{array}$} & \multicolumn{3}{|c|}{ Calcium intake (g) } & \multicolumn{3}{|c|}{$\begin{array}{c}\text { Production performance, } \\
\text { eight to } 21 \text { days }\end{array}$} & \multicolumn{2}{|c|}{ Bone parameter } \\
\hline & & $\begin{array}{c}\text { Diet } \\
\text { basal }\end{array}$ & $\begin{array}{l}\text { Source } \\
\text { calcium }\end{array}$ & $\begin{array}{c}\text { Total } \\
\text { calcium }\end{array}$ & FI & WG & FC & $\begin{array}{l}\text { BA }^{1} \\
(\%)\end{array}$ & $\begin{array}{l}\text { BTS }^{2} \\
\text { (kgf) }\end{array}$ \\
\hline Basal diet & 0.166 & 0.312 & 0.000 & 0.312 & $188.01^{\mathrm{b}}$ & $76.30^{b}$ & $2.46^{\mathrm{a}}$ & $28.61^{\mathrm{b}}$ & $1.23^{\mathrm{f}}$ \\
\hline \multirow{2}{*}{$\mathrm{CaCO}_{3}$} & 0.342 & 0.403 & 0.831 & 1.235 & $243.06^{\mathrm{aA}}$ & $114.15^{\mathrm{aB}}$ & $2.13^{\mathrm{bA}}$ & $39.30^{\mathrm{aB}}$ & $2.87^{\mathrm{deB}}$ \\
\hline & 0.684 & 0.405 & 1.668 & 2.072 & $243.81^{\mathrm{aA}}$ & $119.81^{\mathrm{aA}}$ & $2.04^{\mathrm{bB}}$ & $43.25^{\mathrm{aA}}$ & $4.49^{\mathrm{bA}}$ \\
\hline \multirow{2}{*}{ CMS } & 0.342 & 0.394 & 0.81 & 1.205 & $236.93^{\mathrm{aA}}$ & $111.94^{\mathrm{aA}}$ & $2.12^{\mathrm{bA}}$ & $40.49^{\mathrm{aB}}$ & $3.77^{\mathrm{bcB}}$ \\
\hline & 0.684 & 0.402 & 1.625 & 2.027 & $237.55^{\mathrm{aA}}$ & $117.03^{\mathrm{aA}}$ & $2.03^{\mathrm{bA}}$ & $44.13^{\mathrm{aA}}$ & $5.37^{\mathrm{aA}}$ \\
\hline \multirow{2}{*}{ MS } & 0.342 & 0.393 & 0.828 & 1.221 & $242.15^{\mathrm{aA}}$ & $116.93^{\mathrm{aA}}$ & $2.07^{\mathrm{bA}}$ & $42.00^{\mathrm{aA}}$ & $3.72^{\mathrm{bcA}}$ \\
\hline & 0.684 & 0.393 & 1.621 & 2.014 & $236.94^{\mathrm{aA}}$ & $117.37^{\mathrm{aA}}$ & $2.02^{\mathrm{bA}}$ & $43.01^{\mathrm{aA}}$ & $3.86^{\mathrm{bcA}}$ \\
\hline \multirow{2}{*}{ OS } & 0.342 & 0.398 & 0.82 & 1.218 & $239.75^{\mathrm{aA}}$ & $115.56^{\mathrm{aA}}$ & $2.08^{\mathrm{bA}}$ & $41.30^{\mathrm{aA}}$ & $3.54^{\mathrm{cdA}}$ \\
\hline & 0.684 & 0.399 & 1.644 & 2.043 & $240.31^{\mathrm{aA}}$ & $117.81^{\mathrm{aA}}$ & $2.04^{\mathrm{bA}}$ & $44.25^{\mathrm{aA}}$ & $3.70^{\mathrm{bcA}}$ \\
\hline SEM & & & & & 4.86 & 2.21 & 0.04 & 1.87 & 0.18 \\
\hline
\end{tabular}

$\mathrm{CaCO}_{3}$ : Calcium carbonate; CMS: Charru mussel shell meal; MS: Maçunim shell meal; OS: Oyster shell meal. Means followed by different lowercase letters in the same column differ from each other $(\mathrm{P}<0.05)$ by Tukey's test. Means followed by different uppercase letters in the same variable and calcium source differ from each other $(\mathrm{P}<0.05)$. ${ }^{1}$ Bone ash percent. ${ }^{2}$ Bone tensile strength.

$\mathrm{SEM}=$ standard error of the mean.

There were no differences $(\mathrm{P}>0.05)$ in feed intake between the birds that consumed diets containing calcium carbonate, charru mussel-, maçunim- and oyster-shell meals as the calcium source. These results are in line with those obtained by Carlos et al. (2011), who also did not find significant differences in the feed intake of broiler hens from one to 21 days of age which were fed diets containing calcareous algae as a substitute for calcitic limestone. Studies led by Lana (2017) revealed that broiler hens fed diets containing $0.421 \%$ calcium from charru mussel shell meal had a higher feed intake than the other groups, which were fed different organic calcium sources. Likewise, Oso, Idowu and Niameh (2011) reported higher feed intake and weight gain in broilers fed a diet containing oyster shell as the calcium source when compared with limestone. 
At 21 days of age, re no differences were detected $(\mathrm{P}>0.05)$ for weight gain between the evaluated calcium sources. However, the group fed the diets containing calcium carbonate and charru mussel shell meal showed differences $(\mathrm{P}<0.05)$ between the tested calcium levels. In this respect, the quail fed the diets containing $0.684 \%$ calcium derived from calcium carbonate and from charru mussel shell meal had weight gains of 119.81 and 117.03 g, respectively. Likewise, Lana (2017) reported higher weight gains in broiler hens fed diets containing charru mussel shell meal as the organic calcium source. Rezvani et al. (2019), on the other hand, did not find significant differences in broiler performance using calcium carbonate, oyster shell and eggshell as calcium sources during the experimental period (11 to 39 days).

Feed conversion differed significantly $(\mathrm{P}<0.05)$ between the levels of supplemented calcium $(0.342$ and $0.684 \%$ ) derived from calcium carbonate and from charru mussel shell meal. The birds which consumed diets containing $0.684 \%$ calcium from calcium carbonate and charru mussel shell meal exhibited the best feed conversion ratios (2.04 and 2.03, respectively). This response is explained by the similar feed intake of those birds and the higher weight gain of the group fed diets with higher calcium levels. These findings agree with those obtained by Muniz, Arruda, Fassani, Teixeira and Pereira (2007), who used calcium carbonate, calcium carbochelate and calcitic limestone; and by Lana (2017), after supplementing broiler hen diets with calcium from charru mussel-, maçunim- and oyster-shell meals. Pope, Owens, Cavitt, Emmert and Taylor (2002), in turn, found increased weight gain and improved feed conversion in broilers fed Lithothamnium calcareum.

Bone ash contents did not differ significantly $(\mathrm{P}>0.05)$ between the different tested calcium sources. This finding is in line with those reported by Carlos et al. (2011), who did not observe changes in the production performance or bone ash content of birds fed diets containing calcareous algae as the calcium source. Oso et al. (2011) also did not observe differences in bone ashes between chickens fed oyster shell, snail shell and limestone. Differences were detected $(\mathrm{P}<0.05)$ for bone ash contents between the studied calcium levels. The quail which consumed diets containing $0.684 \%$ calcium derived from charru mussel shell meal and calcium carbonate obtained a higher ash content (44.13\% and $43.25 \%$, respectively) than those fed $0.342 \%$ calcium from the same sources $(40.49 \%$ and $39.30 \%$, respectively).

Significant differences were observed $(\mathrm{P}<0.05)$ for bone tensile strength between the tested calcium sources and levels. Similar findings were reported by Sá, Gomes, Albino, Rostagno and D'Agostini (2004), who used calcium carbonate, dicalcium phosphate, calcitic limestone and dolomitic lime as calcium sources for broiler hens; and by Lana (2017), who evaluated charru mussel-, maçunimand oyster-shell meals for broiler hens. Greater bone tensile strength was obtained by the birds which were fed diets containing $0.684 \%$ calcium from charru mussel shell meal (5.37 kgf) and calcium carbonate (4.49 $\mathrm{kgf}$ ), whereas those fed $0.342 \%$ calcium derived from calcium carbonate obtained the lowest ( $2.87 \mathrm{kgf}$ ) bone tensile strength. The higher bone tensile strength found in the birds fed diets containing $0.684 \%$ calcium derived from charru mussel shell meal suggests that this organic calcium source provided adequate balancing and availability of calcium in the diets, ensuring satisfactory deposition of the mineral for bone stiffness. Similar results were obtained by Viapiana et al. (2015) and Lana (2017), who replaced calcitic limestone with charru mussel shell meal in diets for meat quail and broiler hens, respectively.

The relative calcium bioavailability values obtained by the standard-curve method for all evaluated variables and sources were higher than those observed with the standard source, except for weight gain in the birds fed charru mussel shell meal, whose bioavailability value was $88.51 \%$ (Table 3 ). For feed conversion, oyster shell meal showed the 
highest bioavailability (178.39\%), followed by maçunim shell (161.43\%) and charru mussel shell $(135.25 \%)$ meals. The same was observed for bone ash, whose bioavailability values were 157.02, 151.25 and $147.08 \%$ for oyster-, maçunim- and charru mussel-shell meals, respectively.

Table 3

Relative calcium bioavailability from organic calcium sources, obtained by the standard-curve method, using production performance variables and bone parameters

\begin{tabular}{lcccc}
\hline \multicolumn{1}{c}{ Relative calcium bioavailability (\%) } \\
\hline Parameter & $\begin{array}{c}\text { Calcium } \\
\text { carbonate }^{\mathbf{1}}\end{array}$ & $\begin{array}{c}\text { Charru mussel } \\
\text { shell meal }\end{array}$ & $\begin{array}{c}\text { Maçunim } \\
\text { shell meal }\end{array}$ & $\begin{array}{c}\text { Oyster shell } \\
\text { meal }\end{array}$ \\
\hline Weight gain (g) & 100 & 88.51 & 127.59 & 120.78 \\
Feed conversion & 100 & 135.25 & 161.43 & 178.39 \\
Bone ash content (\%) & 100 & 147.08 & 151.25 & 157.02 \\
Bone tensile strength (kgf) & 100 & 162.04 & 119.92 & 110.74 \\
\hline Mean & 100 & 133.22 & 140.05 & 141.73 \\
\hline
\end{tabular}

${ }^{1}$ Attributed to calcium carbonate $100 \%$ calcium bioavailability for the model used.

Regression equations for the standard source (calcium carbonate):

$W G=108.449+6.819 \times 1\left(\mathrm{R}^{2}=0.62\right)$

$F C=2.2270-0.1146 \times 1\left(\mathrm{R}^{2}=0.55\right)$

$B A=35.428+4.679 X 1\left(\mathrm{R}^{2}=0.53\right)$

$B T S=1.569+1.852 X 1\left(\mathrm{R}^{2}=0.61\right)$.

Charru mussel shell meal stood out with the highest bioavailability coefficient for bone tensile strength (162.04\%), followed by maçunimand oyster-shell meals (119.92 and $110.74 \%$, respectively). Considering the bone performance variables, the charru mussel-, maçunim- and oyster-shell meals showed average relative calcium bioavailability values of $133.22 \%, \quad 140.05 \%$ and $141.73 \%$, respectively. Muniz et al. (2007) described similar results in an experiment with calcium sources for broiler hens, where they found higher relative bioavailability values in calcium carbochelate and limestone (121\% and 103\%, respectively) as compared with the standard source, $\mathrm{CaCO}_{3}$.
Table 4 describes the relative calcium bioavailability values of the marine sources, which were estimated based on the performance variables and bone parameters obtained by the slope ratio (multiple linear regression). Charru mussel shell meal showed the highest relative calcium bioavailability values (119.18\%) of all evaluated marine sources. For weight gain, maçunim shell meal showed the highest relative calcium bioavailability (95.99\%), followed by oyster shell meal (91.57\%), whereas the lowest value was obtained by charru mussel shell meal $(71.51 \%)$. The relative bioavailability of calcium for feed conversion was highest for maçunim shell meal (144.23\%) as compared with the other organic calcium sources. 
Table 4

Relative calcium bioavailability from organic sources of calcium, obtained by the slope ratio method (Multiple Linear Regression), using the production performance variables and bone parameters

\begin{tabular}{lcccc}
\hline \multicolumn{5}{c}{ Relative calcium bioavailability (\%) } \\
\hline \multicolumn{1}{c}{ Parameter } & $\begin{array}{c}\text { Calcium } \\
\text { cabonate }^{\mathbf{1}}\end{array}$ & $\begin{array}{c}\text { Charru mussel } \\
\text { shell meal }\end{array}$ & $\begin{array}{c}\text { Maçunim shell } \\
\text { meal }\end{array}$ & $\begin{array}{c}\text { Oyster shell } \\
\text { meal }\end{array}$ \\
\hline Weight gain (g) & 100 & 71.51 & 95.99 & 91.57 \\
Feed conversion & 100 & 112.26 & $14 ., 23$ & 121.33 \\
Bone ash content (\%) & 100 & 125.87 & $12 ., 34$ & 132.75 \\
Bone tensile strength (kgf) & 100 & 167.09 & 93.21 & 79.25 \\
\hline Mean & 100 & 119.18 & 113.69 & 106.22 \\
\hline
\end{tabular}

${ }^{1}$ Attributed to calcium carbonate $100 \%$ calcium bioavailability for the model used.

$W G=109.716-106.240 X 1+5.907 X 2+4.224 X 3+5.670 X 4+5.409 X 5\left(\mathrm{R}^{2}=0.94\right)$

$F C=2.14330+1.05636 X 1-0.05442 X 2-0.06109 X 3-0.07849 X 4-0.06603 X 5\left(\mathrm{R}^{2}=0.83\right)$

$B A=37.619-28.627 X 1+3.102 X 2+3.905 X 3+3.764 X 4+4.118 X 5\left(\mathrm{R}^{2}=0.87\right)$

$B T S=2.5394-4.1263 X 1+1.0186 X 2+1.7020 X 3+0.9494 X 4+0.8773 X 5\left(\mathrm{R}^{2}=0.88\right)$

Where $\mathrm{X} 1=$ calcium intake from basal diet; $\mathrm{X} 2=$ calcium intake from calcium carbonate; $\mathrm{X} 3=$ calcium intake from

charru mussel shell meal; X4= calcium intake from maçunim shell meal; X5=calcium intake from oyster shell meal.

The relative bioavailability of calcium for feed conversion and for the bone ash contents in the organic calcium sources was higher than that of the standard source $\left(\mathrm{CaCO}_{3}\right)$. For the bone ash contents, oyster shell meal exhibited higher calcium bioavailability than charru mussel- and oyster-shell meals.

The relative calcium bioavailability values obtained for bone tensile strength were $167.09 \%$ in charru mussel shell meal and 93.21 and $79.25 \%$ and in maçunim- and oyster-shell meals, respectively.

Considering the production performance variables and bone parameters, the average calcium bioavailability values were $119.18 \%$ for charru mussel shell meal, $113.69 \%$ for maçunim shell meal and $106.22 \%$ for oyster shell meal. These relative values are similar to those reported by Lana (2017), who examined organic sources of calcium for broiler hens and found the coefficients of $106.94 \%$ for charru mussel shell meal, $101.27 \%$ for maçunim shell meal and $91.11 \%$ for shell meal.

When estimated based on each of the analyzed variables, the relative calcium bioavailability values for charru mussel-, maçunim- and oyster-shell meals might have been influenced by the degree of grinding or particle size of the tested sources.

\section{Conclusion}

This study suggests that charru mussel-, maçunim- and oyster-shell meals can be used as organic sources of calcium in the diet of quail, as they have no negative effect on the performance of European quail. In addition, these ingredients exhibited high digestibility and showed to be highly bioavailable, with bioavailability values greater than $100 \%$. Therefore, the use of these alternative calcium sources in poultry feed can favor the development of a more sustainable poultry farming, since they can be used in animal feed instead of being disposed in and polluting the environment.

\section{Acknowledgments}

The present study was supported by the Coordination for the Improvement of Higher Education Personnel - Brazil (CAPES) - Funding code 001 . 


\section{References}

Carlos, A. C., Sakomura, N. K., Pinheiro, S. R. F., Toledano, F. M. M., Giacometti, R., \& Silva, J. W., Jr. (2011). Uso da alga Lithothannium calcareum como fonte alternativa de cálcio nas rações de frangos de corte. Ciência Agrotecnologia, 35(4), 833-839. doi: 10.1590/S1413-70542011000400025

Kim, J. H., Jung, H., Pitargue, F. M., Han, G. P., Choi, H. S., \& Kil, D. Y. (2017). Effect of dietary calcium concentrations in low non-phytate phosphorus diets containing phytase on growth performance, bone mineralization, litter quality, and footpad dermatitis incidence in growing broiler chickens. AsianAustralas Journal Animal Science, 30(7), 979-984. doi: 10.5713/ajas.17.0112

Lana, G. R. Q. (2017). Fontes de cálcio da região costeira de Alagoas em dietas para frangos de corte. Tese doutorado, Universidade Federal de Alagoas, Rio Largo, AL, Brasil.

Muniz, B. E., Arruda, A. M. V., Fassani, E. J., Teixeira, A. S., \& Pereira, E. S. (2007). Avaliação de fontes de cálcio para frangos de corte. Revista Caatinga, 20(1), 5-14. Retrived from https://www.redalyc.org/ articulo.oa? $\mathrm{id}=237117747002$ :

Oso, A. O., Idowu, A. A., \& Niameh, O. T. (2011). Growth response, nutrient and mineral retention, bone mineralisation and walking ability of broiler chickens fed with dietary inclusion of various unconventional mineral sources. Journal of Animal Physiology and Animal Nutrition, 95(4), 461-467. doi: 10.1111/j.1439-0396.2010.01073.x

Pope, H. R., Owens, C. M., Cavitt, L. C., Emmert, J. L., \& Taylor, S. J. (2002). Efficacy of Marigro in supporting growth, carcass yield and meat quality of broilers. Proceeding of the Annual Meeting Abstracts, The Southern Poultry Science Society, 81, Newark, DE, USA, 91. Retrived from https:// poultryscience. org/files/galleries/2002_IPSF_Abstracts.pdf
R Core Team (2016). A language and environment for statistical computing. Vienna, Austria: R Foundation for Statistical Computing. Retrived from https:// www.R-project.org/

Rezvani, M. R., Moradi, A., \& Izadi, M. (2019). Ileal digestibility and bone retention of calcium in diets containing eggshell, oyster shell or inorganic calcium carbonate in broiler chickens. Poultry Science Journal, 7(1), 7-13. doi: 10.22069/ psj.2019.14720.1319

Sá, L. M., Gomes, P. C., Albino, L. F. T., Rostagno, H. S., \& D’Agostini, P. (2004). Exigências nutricionais de cálcio e sua biodisponibilidade em alguns alimentos para frangos de corte no período de 1 a 21 dias de idade. Revista Brasileira de Zootecnia, 33(1), 157168. doi: 10.1590/S1516-35982004000100020

Sakomura, N., \& Rostagno, H. S. (2007). Métodos de pesquisa em nutrição de monogástricos. Jaboticabal, SP: FUNEP.

Santana, A. L. A., Teixeira, A. O., Lopes, D. C., Santana, R. A., Rocha, C. M., Jr., Moreira, L. M., Corassa, A. (2018). Digestibility of calcium and digestible calcium from inorganic sources evaluated in swine by two methods. Revista Brasileira de Saúde e Produção Animal, 19(1), 93-104. doi: 10.1590/ S1519-994 02018000100009

Silva, D. J., \& Queiroz, A. C. (2006). Análise de Alimentos: métodos químicos e biológicos. Viçosa, MG: UFV.

Silva, J. H. V., \& Costa, F. G. P. (2009). Tabela para codornas japonesas e europeias. Jaboticabal, SP: FUNEP.

Viapiana, J. G., Lana, G. R. Q., Lana, S. R. V., Ferreira, J. O., Madalena, J. A. S., Lana, A. M. Q.,... Barros, R. F., Jr. (2015). Influência da casca de sururu em rações de codornas europeias sobre o rendimento de carcaça e resistência óssea. Anais do Congresso Brasileiro de Zootecnia, Fortaleza, CE, Brasil, 25. 
